\title{
Explaining firm-level total factor productivity in post-transition: manufacturing vs. services sector
}

\section{Valerija Botrić}

Department for Labor Markets and Social Policy,

The Institute of Economics, Zagreb

Croatia

Email:vbotri@eeizg.hr

\section{Ljiljana Božić}

Department for Innovation, Business Economics and Business Sectors,

The Institute of Economics, Zagreb

Croatia

Email:ljbozic@eizg.hr

\section{Tanja Broz}

Department for Macroeconomics and International Economics,

The Institute of Economics, Zagreb

Croatia

Email:tbroz@eizg.br

Abstract. Post transition economies carry the legacy of previous system, supposed to have collapsed in partly due to inability to sustain innovation and technical progress. In terms of innovation activity, they still lag behind advanced market economies. This brings the issue of total factor productivity (TFP) for these countries/industries/firms in focus of research interest. Relying on the TFP firmlevel estimates from the World Bank' Enterprise Survey dataset, we analyse the main contributing factors in following post-transition economies: Georgia, Turkey, Ukraine, Russia, Romania, Bosnia and Herzegovina, FYR Macedonia, Mongolia, Slovenia and Croatia. The potential determinants include variables frequently named in the literature: R\&D efforts, human capital, ICT investment, competition (product market regulation) and international trade. The data for the TFP determinants is drawn from Business Environment and Enterprise Performance Survey (BEEPS V), which includes both objective variables and perceptions of firms' management. Since many objective variables are simultaneously determined with our dependent variable, we argue that by relying on perceptions we omit the endogeneity issue. In addition to aggregate firm-level TFP determinants, we also distinguish between the manufacturing and service sector. The aim of the research is to emphasize the structural differences between these two segments of post-transition economies.
Received:

June, 2017

1st Revision:

August, 2017

Accepted:

September, 2017

DOI:

10.14254/2071$8330.2017 / 10-3 / 6$ 
Keywords: technology progress, total factor productivity, post-transition countries.

JEL Classification: D24, O33, L25

\section{INTRODUCTION}

Post transition economies' policy makers have proclaimed similar goal - to catch up with developed market economies and thus ensure higher standard of living for their citizens. Catching up can be obtained through extensive investment in capital and labour and through increase in total factor productivity (TFP). Growth accounting literature argues that the main source of convergence is not through capital and labour increases, but through TFP (Solow 1957; Dowrick, \& Nguyen 1989; Easterly, \& Levine 2001; Wang, \& Yao 2003). Notwithstanding restructuring post transition economies have gone through, they are still on average far from the frontier of the advanced market economies in terms of innovation activity and technology - as documented, for example, by the indicators in the European Union Innovation Scoreboard (European Commission, 2017). It seems that the legacy of previous system, which is supposed to have collapsed in part due to inability to sustain innovation and technical progress, is still preventing post transition economies to close the gap.

Literature on total factor productivity is mostly focused on the developments in the overall economy, while research of industries is less in focus. Bah and Brada (2009) argue that TFP level is lower in transition countries than in advanced economies. This leads to the assumption that transition towards market economy and subsequently convergence process should be marked up by intensified TFP growth. Structure of the economy is important in that respect. Existing literature suggests large and persistent heterogeneity in firmlevel productivity, even in narrowly defined industries, across the countries (Bartelsman, Haltiwanger, \& Scarpetta, 2013). Hence, the objective of this paper is to seek main contributing factors of total factor productivity at the firm level in post-transition economies. The empirical contribution in this paper is constraint by the available data - comparable firm level TFP estimates for the transition economies became available in August 2016 (Cusolito, et. al., 2016), with the data referring to the latest available survey round of the Environment and Enterprise Performance Survey (BEEPS) conducted regularly by the European Bank for Reconstruction and Development (EBRD). Based on this dataset, we analyse the main contributing factors in all post-transition economies for which the data was available, that is: Bosnia and Herzegovina, Croatia, FYR Macedonia, Georgia, Mongolia, Romania, Russia, Slovenia, Turkey and Ukraine. To the best knowledge of the authors this is the first attempt to provide insight into the firm-level TFP determinants analysis based on the methodology-consistent dataset in these countries.

The paper takes following structure. Next section reviews the literature on the differences in total factor productivity and main determinants of TFP. Section 3 describes data and gives details about the methodology, while section 4 discusses results. Last section concludes.

\section{LITERATURE REVIEW}

The differences in the level of economic development across the countries have long been associated with the differences in technological knowledge (Romer, 1993). This has been emphasized in numerous studies on TFP differences (Hall, \& Jones, 1999). Acemoglu and Zilibotti (2001), however, argue that it is hard to explain persistent differences across countries since they should decline in time due to factor mobility. The authors propose that persistent differences are related to technology-skill mismatch, even in cases when there are no barriers to technology transfer. This implies that in order to climb the technology ladder, certain absorptive capacity and (possibly specific) human capital is needed. Through exposure to 
advancements in technology additional $\mathrm{R} \& \mathrm{D}$, creativity and technological process becomes achievable, contributing to virtuous growth path.

A problem with the international comparison of aggregate TFP growth is that it does not take into account differences in the weights of sectors within the national economies. If in two countries the same industries have equal TFP growth but a different economic weight, aggregate TFP growth will differ between the two countries. Thus, even if market competition forces determine the outcomes at the industry level, the outcome at the national level might differ. This warrants a closer look at the evolution of TFP at the industry level. Previous empirical analysis has documented persistent TFP differences at the industry level even among developed economies (Harrigan, 1999), yet similar research in transition economies is scarce due to the lack of comparable data.

Most often in the literature TFP is defined as a variation in output that cannot be attributed to variations in production inputs (Krugman, 1994; Hulten, 2001; Helpman, 2004). Since TFP is nonobservable variable, there are many methodological issues related to its estimation. Van Beveren (2010) lists problems arising when the TFP is estimated using the traditional OLS: simultaneity or endogeneity problem, selection bias, proxying for firm-level prices using industry-level deflators and problem of multi-product firms. Hence, alternative methods have been established. Besides non-parametric methods, fixed effects estimation, instrumental variables, generalized method of moments, most popular way to estimate TFP are semi-parametric estimations following methodologies proposed by Olley and Pakes (1996) and Levinsohn and Petrin (2003). They use firm's investment decision and exit rule (Olley, \& Pakes, 1996) and intermediate inputs (Levinsohn, \& Petrin, 2003), in order to solve simultaneity problem and/or sample selection bias. The estimates used in this paper follow this approach.

The main determinants of (industry-level) total factor productivity (growth) that have been put forward in the literature are: R\&D efforts, human capital, ICT investment, competition (product market regulation) and international trade. Firms invest in R\&D activities in the hope that these activities will result in product, process or organisational innovation, an increase in productivity, improved quality or reduced production costs of existing goods or more variety in final goods or intermediate inputs. These activities will in turn enable their survival on the competitive market and/or increase their profitability.

Castellacci (2007) analysed European countries, and indicated that sectoral differences in productivity growth can be attributed to conditions of appropriability, levels of technological opportunities, levels of education and skill, degree of openness to foreign competition, and size of the market. Jung and Lee (2010) consider economic sector (patent registration in industry, relative import of machinery, economic concentration within an industry) and firm-level variables (share of exports in total sales, relative wages in relation to economic sector, patents the firm registers, expenditure on workers' education relative to sales, number of employees) as relevant factors explaining productivity catching up. İmrohoroğlu and Tüzel (2014) suggest that firm-level TFP is related to firm's size, the book to market ratio, investment and hiring rate.

Innovations are often studied in terms of its relationship with productivity, since the motives for innovation at the firm level are linked to the productivity enhancements. Large body of evidence on innovation-productivity relationship at the firm level builds on CDM model (Crépon, Duguet, \& Mairesse, 1996). By reviewing extant empirical findings on this issue Hall and Mairesse (2006) conclude that the relationship between innovation and productivity is positive. According to Pianta and Vaona (2007) productivity growth in Europe is encouraged by both product and process innovation. The same is found for Latin American countries (Crespi, \& Zuñiga, 2012). However, according to Griffith et al. (2006), result for relationship between different types of innovation and productivity across European countries are not uniform. In the more recent review of empirical evidence Mohnen and Hall (2013) conclude that both 
technological (i.e. product and process innovations) and non-technological (i.e. organizational and marketing) innovations contribute to productivity growth. Goedhuys (2007) finds both R\&D and product innovation significant contributors to productivity growth.

According to de la Fuente (2011), investment in quantity and quality of education is very powerful tool for increasing productivity. The quality of labour, mostly proxied by educational attainment, together with $\mathrm{R} \& \mathrm{D}$, is one of the most emphasised determinants of total factor productivity. Issakson (2007) in his extensive review on TFP determinants argues that increase in the quality of labour enhances absorptive capacity and thus technology transfer. There is, however, a distinction between basic and university education, where university education is necessary factor for technological innovation. Lynch and Black (1996) also show that quality of education is important for productivity in manufacturing and nonmanufacturing sectors.

Transition processes had positive influence on TFP growth rates in some of the countries (Raguž, Družić, \& Tica, 2012). Privatization and foreign ownership, for example, resulted in better performance in terms of TFP (Angelucci et al., 2002). However, it is worth noting that transition economies are rather heterogeneous in catching up with developed economies, some of them demonstrating no improvements of productivity (Bah, \& Brada, 2009). The question of reasons for such diversities is still without final answer in the economic literature. Inspired by the findings in literature, we turn the focus to the empirical analysis of the dataset in the next section.

\section{PRELIMINARY EVIDENCE, DATA SOURCES AND EMPIRICAL STRATEGY}

Figure 1 shows growth of total factor productivity from the start of transition period in the analysed economies ${ }^{1}$. Turbulent period is observed in the 90 s with strong decrease in TFP growth in the first half of the decade and the subsequent rebound in the second half. After year 2000 TFP growth remained positive, oscillating on average around 3 percent. Economic crisis of 2008-2009 is evident from the data, but the decline in the recent crisis is moderate when compared to turbulent early phase of transition. However, the consequences of the latest crisis are still evident in the TFP growth rates, which on average from 2010 barely achieve positive values.

In order to provide deeper insight behind aggregate TFP dynamics, we seek to understand firm-level drivers in analysed economies. Recently released World Bank's (WB) Enterprise Analysis unit ${ }^{2}$ firm-level TFP data enables deeper analysis, since it provides firm-level TFP estiamtes based on the same methodology across the countries. The data is available on the cross-section basis and TFP is estimated using the data from Enterprise Survey. The Survey has been collected by face-to-face interviews with top managers and business owners of enterprises in 40 different industries. WB's methodology for estimating TFP assumes using revenues and costs for all variables (instead of number of man-years hired for production for proxing the labour as in Levinsohn and Petrin, 2003), which is conditioned by the questions available in the Enterprise Survey. Data are transformed to common currency (USD) and deflated using the US GDP deflator. Fixed effects regressions are then run for each industry separately. The process enables obtaining a comparable dataset based on the same methodology and denominated in the same currency. There are, however, two different TFP indicators:

\footnotetext{
${ }^{1}$ Data for Mongolia is missing.

${ }^{2}$ The data is released in August 2016. More details on WB' methodology for estimating TFP can be found in Cusolito, Francis, Karalashvili and Meza (2016).
} 


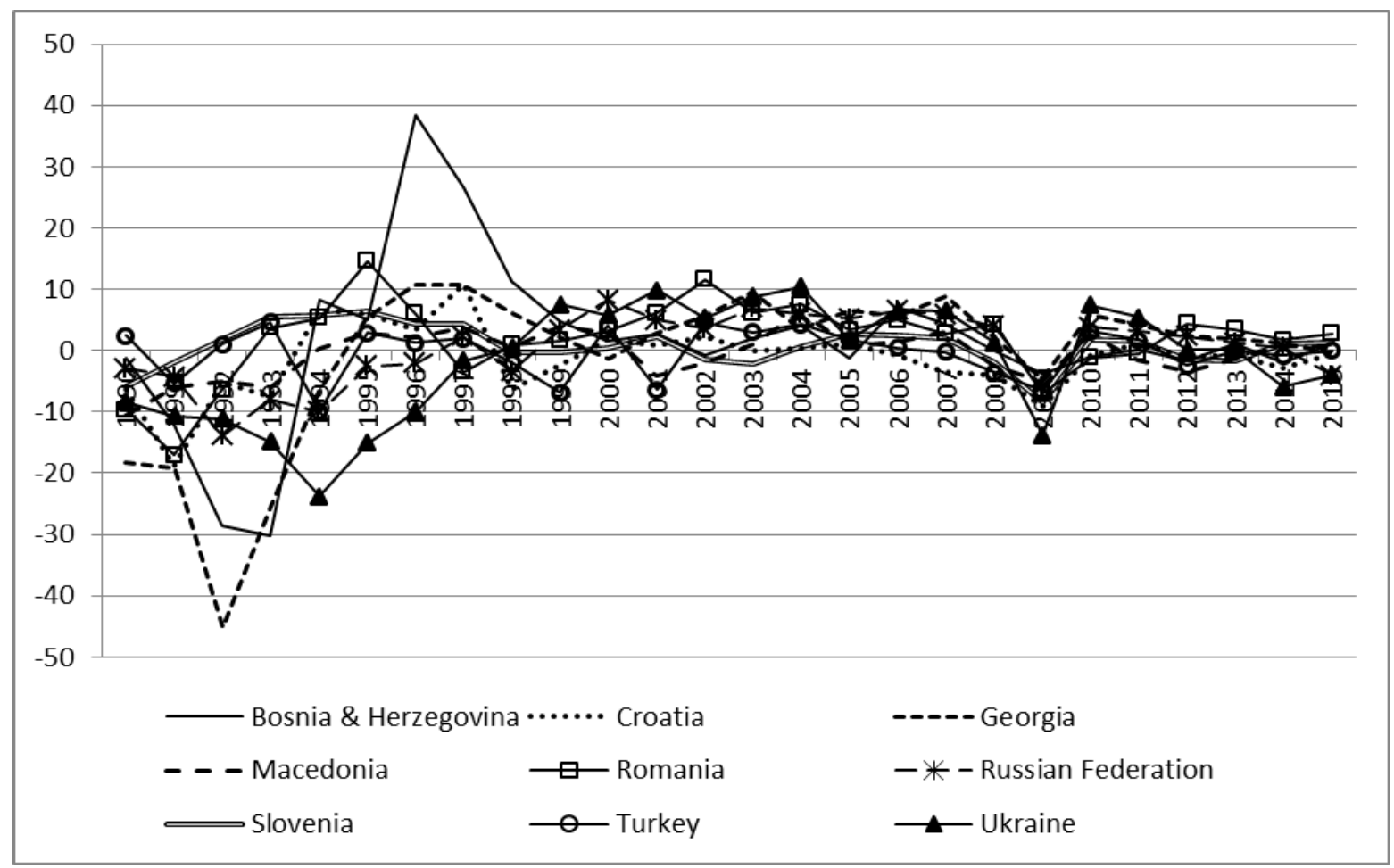

Figure 1. Growth of total factor productivity in the sample countries, in \%

Note: The data on TFP are adjusted in a way that ICT investment is deflated using ICT price deflators as developed by Byrne and Corrado (2016).

Source: The Conference Board, Total Economy Database (2016)

- (i) estimated using capital proxied by the replacement value of machinery, vehicles and equipment and labour proxied by total annual cost of labour (tfprYKL variable)

- (ii) estimates also include other inputs proxied by total annual cost of inputs (tfprYKLM variable).

In order to analyse TFP determinants, we additionally rely on WB dataset for explanatory variables. Specifically we use the data from the latest round of Business Environment and Enterprise Performance Survey $^{3}$ (BEEPS V) conducted by the EBRD and the WB. BEEPS survey includes both objective variables (such as number of employees or the size of the enterprise) and perceptions of firms' management. Since many objective variables are simultaneously determined with our dependent variable, we argue that by relying on perceptions we omit the endogeneity issue. The data from BEEPS are collected for 30 central, eastern and south European countries (including Turkey). However, only for 10 countries we were able to match BEEPS data with TFP data. Hence, our sample comprises from nine post-transition countries (Bosnia and Herzegovina, Croatia, FYR Macedonia, Georgia, Mongolia, Romania, Russia, Slovenia and

\footnotetext{
${ }^{3}$ More information on BEEPS V is available on http://ebrd-beeps.com/. The full database contains responses from 15,883 manufacturing and services firms in 30 EBRD countries gathered by employing face-to-face interviews with business owners or top managers. The data collection started in Russia in 2011-2012, covering 4,220 enterprises in 37 regions, followed by other countries in 2012-2014. The data is available for research analysis free of charge since October 2015. It has to be mentioned that only the data from the core questionnaire have been used in this paper - the full 56 pages long questionnaire can be downloaded at http://ebrd-beeps.com/wp-content/uploads/2013/09/beeps v q cor.pdf. In order to save space, we refer interested reader to the questionnaire to see how the specific questions have been phrased in the interviews.
} 
Ukraine) and Turkey. The sample refers to the period 2012-2013, since this is the last data available from the BEEPS survey.

TFP in manufacturing and services

\begin{tabular}{|c|c|c|c|c|c|}
\hline & $\begin{array}{c}\text { Number of } \\
\text { observations }\end{array}$ & Mean & $\begin{array}{l}\text { Standard } \\
\text { deviation }\end{array}$ & Minimum & Maximum \\
\hline \multicolumn{6}{|c|}{ TFP indicator: tfprYKL } \\
\hline - Manufacturing & 662 & 2.20 & 1.59 & -1.24 & 14.75 \\
\hline - Services & 190 & 3.24 & 1.81 & -0.33 & 7.86 \\
\hline \multicolumn{6}{|c|}{ TFP indicator: tfprYKLM } \\
\hline - Manufacturing & 567 & 2.43 & 1.23 & -0.13 & 14.25 \\
\hline - Services & 171 & 2.12 & 0.88 & 0.55 & 6.70 \\
\hline
\end{tabular}

Source: authors' estimates based on WB data.

Table 1 shows summary statistics for TFP in manufacturing and service sectors. Depending on the TFP indicator, we have in total 852 or 738 observations, with more than three quarter of observations belonging to the manufacturing sector. The data in Table 1 clearly shows that it is important for the subsequent analysis which indicator for TFP we are referring to. TFP indicator tfprYKL shows large difference in average TFP between manufacturing and services, with services achieving higher average productivity. On the other hand, according to tfprYKLM indicator, manufacturing sector has higher average productivity than service sector, although the difference is not that pronounced as with the tfprYKL indicator.

It has to be emphasized, though, that the service sector data is concentrated in only two analysed countries - Russia and Turkey, and the sample is disproportionally skewed towards Russia. Furthermore, Russia, Turkey and Ukraine form the major proportion of manufacturing sector sample. Since these three countries are comparatively larger (in many aspects) than other transition economies, the structure of the sample is not surprising.

If we focus on manufacturing sector, we can explore the differences between specific TFP measures among the analysed countries (Figure 2). In some countries TFP measure omitting inputs (tfprYKL) yields higher TFP estimates (Bosnia and Herzegovina and Russia), with contrary evidence in other countries. This provides additional reason for continuing with the analysis of both alternative measures of TFP.

Our empirical analysis proceeds in two directions. One venue of research seeks main contributors to the firm-level TFP differences in the manufacturing sector and another is focused on differences between manufacturing and services in Russia (for which there are enough TFP firm level estimates in both analysed economic sectors).

We rely on simple OLS estimates. Our potential list of factors contributing to firm-level differences in TFP was rather extensive. Following the assumption that determinants identified in the previous literature at the industry level as well as those at the firm level should be considered, BEEPS data provided a large set of indicators. However, in order to avoid multicollinearity, we restricted the focus on following: 


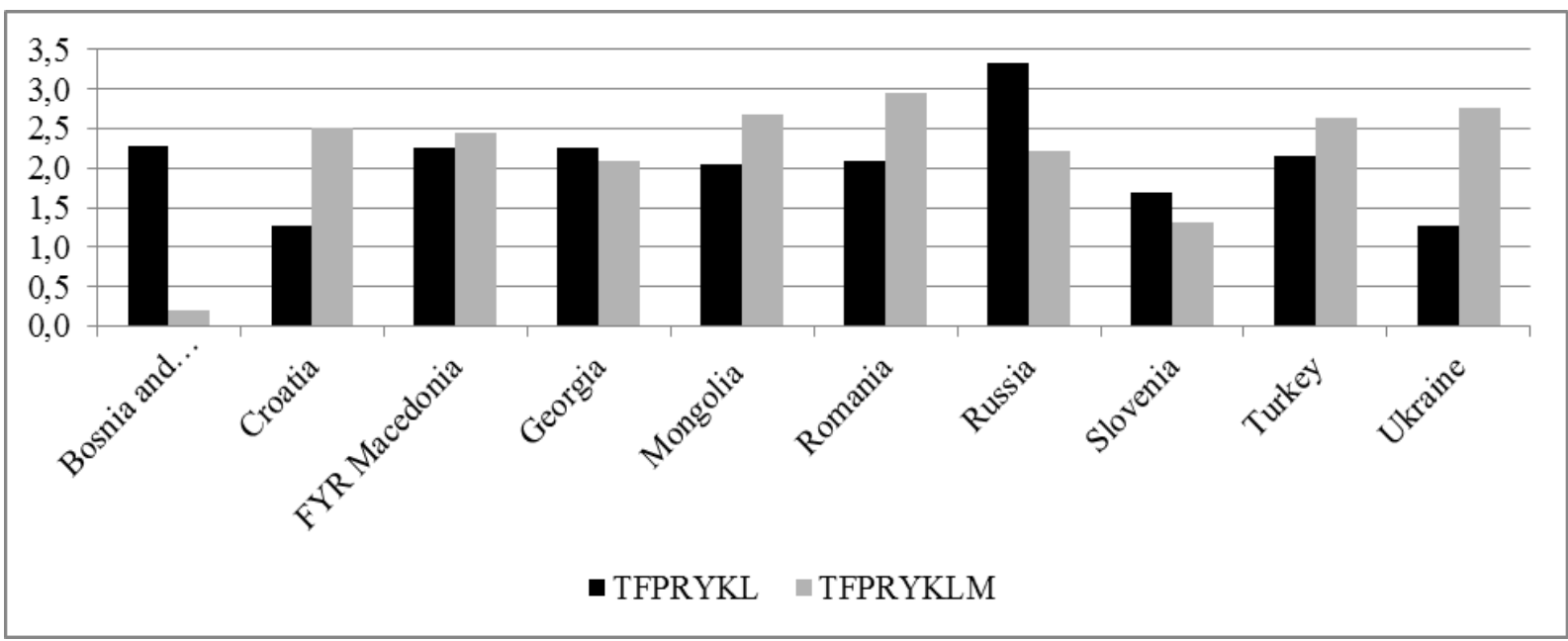

Figure 2. TFP in manufacturing sector

Source: The World Bank.

- Whether a firm is innovative. Innovative firm is defined as one having during the last three years (1) successfully developed new or significantly improved product, production/supply practice, organisational/management practices or structures, marketing methods and logistical or business process, and/or (2) invested in (intermural or extramural) $R \& D$ and/or gave employees time to develop or try out a new approach or new idea about products or services, business process, firm management or marketing. The link between innovation and productivity has been explored extensively in the literature.

- Size of the firm. In order to address this issue we include dummy variables for micro, small, medium (reference variable) and large firm. Size of the firm is documented as important productivity determinant in the literature, at the firm level it is directly related to the economies of scale.

- Export_share is variable capturing the share of exports in total sales of the firm. Competition related to the participation on the foreign market can drive the need for firm-level productivity enhancements.

- ICT investment is captured by two different aspects: does the establishment have its own web site (variable Web) and does this establishment have a high speed Internet access on its premises (variable Internet).

- Ownership of firm is captured by a series of dummy variables referring to whether it was established as state-owned, joint venture, by privatization or as a subsidiary of a larger enterprise, with private being the reference value. Literature documents importance of privatization in transition economies for differences in firm-level productivity growth.

- Foreign material variable captures the share of imports in production inputs, capturing both the link to the global market and the possibility that imported products also imbed additional productivity.

- Technology license variable captures the link to the global market, by indicating whether establishment at present use technology licensed from a foreign-owned company.

- Country dummy variables. Based on the preliminary insights, Russia stands out in comparison to other economies, so it has been used as a reference country ${ }^{4}$. ${ }^{4}$ As is well known, it is not feasible to include all dummy variables in the estimation simultaneously since it would not be possible
to calculate the inverse of the matrix because of perfect collinearity. Therefore, the practical solution commonly used is to omit 
The second segment of analysis, which is focused only on Russia, rests on the t-test of the differences in mean outcomes of firm-level TFP in services and manufacturing.

\section{RESULTS AND DISCUSSION}

The first segment of the analysis is presented in Table 2. As explained in the previous section, these estimates are based on all the manufacturing firms in the countries. Also as explained in previous section, all dummy variables cannot be included simultaneously 5 .

Our results ${ }^{6}$ suggest that country dummy variables are significant factor explaining TFP. This is more pronounced when tfprYKL measure is concerned, where the fact that a firm operates in a country other than Russia results in all cases in significantly lower TFP in manufacturing sector ${ }^{7}$.

We have established positive correlation between productivity and exporting in both specifications ${ }^{8}$. This implies that relatively more productive firms from transition economies are those that successfully compete on the international market. The causalities of the relationship are debatable - whether higher productivity leads to successful export or exposure to foreign competitions creates productivity pressures. Since the analysis rests on the cross-section data, the dataset does not allow further investigation of this issue.

Another significant relationship in both specifications implies that micro firms in manufacturing sector have lower estimated TFP'. This could be attributed to the economies of scales, required in specific industries to achieve appropriate productivity level. However, in the case of post-transition economies it could be additionally related to the pronounced advocacy for the large production enterprises still lingering in the economic structures. The economic and financial sustainability of such large production enterprises is frequently debated in the context of the type and relative success of privatization process.

It is somewhat interesting that empirical analysis suggests negative relationship between TFP and foreign-owned technology license, significant in the case of tfprYKL estimates. However, as argued by Acemoglu and Zilibotti (2001), this might be related to the technology-skill mismatch in post-transition countries. Public debates in these economies frequently emphasize the need of the educational system to adapt to the labour market needs. The problem is that not only the educational attainment level of the workforce is important, but the actual learning content provided by the educational institutions should be upgraded. It is relatively hard to measure these qualitative aspects, so we leave these questions for future research endeavours.

\footnotetext{
one of the dummy variables. The consequence of such approach is that other estimated coefficients are interpreted as departure from omitted variable. We would like to thank the reviewer for suggestion to explain our approach in more details.

5 This is the reason why we can find estimates for all the dummy variables in the Table except Russia. For the interpretation of the coefficients, please consult previous note. We would like to thank the reviewer for suggestion to provide more details on these issues.

${ }^{6}$ Following suggestion from reviewer, in addition to estimated coefficients and standard errors, an interested reader can find tstatistics and p-values in Table A1 in the Appendix.

${ }^{7}$ It can be seen that the estimated coefficients in Table 2 are significant at the 1 percent level in all cases when dependent variable is tfprYKL.

8 As it can be seen from the results in Table 2, the coefficient in both specifications for the „export“ variable is positive and significant. Since the dataset in our analysis is cross-sectional, we do not suggest that our results can be interpreted in a structural way.

${ }^{9}$ As it can be seen from the results presented in Table 2, in both specifications the dummy variable indicating micro firm is negative and significant.
} 
Factors explaining firm-level TFP differences in manufacturing sector

\begin{tabular}{|c|c|c|}
\hline & $\begin{array}{c}\text { dependent variable: } \\
\text { tfprYKL } \\
\text { estimated coefficient (standard error) }\end{array}$ & $\begin{array}{c}\text { dependent variable: } \\
\text { tfprYKLM } \\
\text { estimated coefficient (standard error) }\end{array}$ \\
\hline Constant & $3.64 * * *(0.23)$ & $2.40^{* * *}(0.19)$ \\
\hline Innovative firm & $0.01(0.12)$ & $-0.16(0.10)$ \\
\hline \multicolumn{3}{|l|}{ Size of the firm } \\
\hline Micro & $-1.23 * * *(0.47)$ & $-0.74 *(0.40)$ \\
\hline Small & $-0.12(0.13)$ & $-0.14(0.12)$ \\
\hline Large & $-0.04(0.17)$ & $-0.07(0.15)$ \\
\hline Internet & $-0.25(0.16)$ & $-0.13(0.14)$ \\
\hline Web & $0.03(0.13)$ & $0.14(0.12)$ \\
\hline Technology_licence & $-0.29 *(0.15)$ & $-0.12(0.13)$ \\
\hline Foreign_material & $0.00(0.00)$ & $0.00(0.00)$ \\
\hline Export_share & $0.01 *(0.00)$ & $0.01 * * *(0.00)$ \\
\hline \multicolumn{3}{|l|}{ Establishment formation } \\
\hline State & $0.15(0.55)$ & $0.08(0.44)$ \\
\hline Joint & $0.24(0.60)$ & $0.41(0.48)$ \\
\hline Privatization & $-0.20(0.20)$ & $0.00(0.17)$ \\
\hline Subsidiary & $-0.28(0.60)$ & $-0.08(0.48)$ \\
\hline \multicolumn{3}{|l|}{ Countries } \\
\hline Georgia & $-1.22 * * *(0.37)$ & $-0.25(0.33)$ \\
\hline Turkey & $-1.23 * * *(0.17)$ & $0.32 * *(0.15)$ \\
\hline Ukraine & $-2.02 * * *(0.18)$ & $0.56^{* * *}(0.15)$ \\
\hline Romania & $-1.59 * * *(0.41)$ & $0.32(0.34)$ \\
\hline Bosnia and Herzegovina & $-1.16^{* * *}(0.36)$ & $-2.18 * * *(0.32)$ \\
\hline FYR Macedonia & $-1.06^{* * *}(0.33)$ & $0.27(0.28)$ \\
\hline Mongolia & $-1.33 * * *(0.40)$ & $0.48(0.32)$ \\
\hline Slovenia & $-1.95 * * *(0.41)$ & $-1.31 * * *(0.33)$ \\
\hline Croatia & $-2.09 * * *(0.36)$ & $0.31(0.29)$ \\
\hline \multicolumn{3}{|c|}{ Diagnostics } \\
\hline Number of observations & 642 & 552 \\
\hline Rsq & 0.22 & 0.19 \\
\hline F-test & $7.91 * * *$ & $5.60^{* * *}$ \\
\hline
\end{tabular}

Source: authors' estimates based on WB data. *** denotes significance at 1 percent, ${ }^{* *}$ denotes significance at 5 percent, * denotes significance at 10 percent.

Although innovations are mostly recognized for its contribution to productivity growth, there is evidence that they in fact do not impact productivity in case of developing economy (e.g. Benavente, 2006). Hall and Mairesse (2006) interpreted the finding as an indicator of different circumstance in which firms in developed and developing economies innovate. Our results also do not imply that there is significant contribution of innovation to firm-level TFP. We have also performed simple t-test on the differences in 
mean-TFP outcomes conditional upon whether the firm is innovative or not ${ }^{10}$, and the differences in outcomes was not significant. However, the relationship between innovation and productivity is evolving in time, and could not be fully captured by the cross-sectional data used in this paper.

We turn our attention next to the analysis focused on Russia, with results presented in Table 3.

Table 3

TFP differences between manufacturing and services in Russia

\begin{tabular}{|l|c|c|c|c|c|}
\hline & $\begin{array}{c}\text { Number of } \\
\text { observations }\end{array}$ & Mean & $\begin{array}{c}\text { Hypothesis } \\
\text { Diff=0 }\end{array}$ & $\begin{array}{c}\text { Hypothesis } \\
\text { Diff }<\text { 0 }\end{array}$ & $\begin{array}{c}\text { Hypothesis } \\
\text { Diff }>\mathbf{0}\end{array}$ \\
\hline TFP indicator: tfprYKL & 140 & 3.33 & $\mathrm{p}=0.93$ & $\mathrm{p}=0.53$ & $\mathrm{p}=0.46$ \\
\hline - Manufacturing & 217 & 3.35 & & $\mathrm{p}=0.06$ & $\mathrm{p}=0.94$ \\
\hline
\end{tabular}

Source: authors' estimates based on WB data.

The results in Table 3 show that although descriptive statistics implies large differences between manufacturing and service sector TFPs, especially for the tfprYKL indicator, when we focus only on the country for which there is relative abundance of individual firm-level TFP estimates, the differences in tfprYKL still remain but are not statistically significant, as indicated by the reported p-values. Service sector's share in the overall economic structure is increasing; even the share of services in international trade is increasing. Yet, the adequate indicators to measure the productivity of the service sector remain unknown. Subsequently, large sections of the reason for differences in country productivity growth are not given enough concern in the policy discussions. More attention should be devoted to the developments in the service sector, in particular in the post-transition economies, where remarkable dynamics of private entrepreneurship in the service sector has occurred. Additional importance of the service sector productivity is related to the aging society problem, present also in the case of transition economies. Not only that the demand for the services will increase (specifically in terms of health and personal services), the innovativeness of the supply side could be challenged by the aging workforce.

The long-term analysis of productivity growth reveals the slowing-down pattern, frequently attributed to the nature of technological progress or the changing structure of economies (ECB, 2017). When considering future productivity dynamics, it has to be noted that the effects of the recent global economic crisis are still to be assessed. The crisis itself can be viewed either as the one having long-term scarring effect on the future productivity growth or through the lenses of Schumpeterian creative destruction mechanism. Although transition countries have regained positive momentum, it is still early to assess which pathway prevails. OECD (2015) report, for example, suggests that the gap between global leaders in productivity and

10 Although not shown here, similar exercise has been performed related to the variable capturing university share of employees with similar results. We were not able to find evidence that enterprises with higher share of university graduates have higher TFPs. 
others is increasing, in particular in the service sector. It is further emphasized that productivity growth patterns depend on the type of firms considered - globally most productive firms, nationally most productive firms or the firms that are not at the productivity frontier.

Policy areas important to sustain productivity growth are (OECD, 2015):

- fostering innovation at the global productivity frontier in order to maintain the global productivity growth, but at the same time enable knowledge diffusion to the leaders at the national level

- creating favourable business conditions to the most productive firms, facilitating technology diffusion in the society

- reducing resource misallocations, in particular those related to the human capital - the problem of skills mismatch. Also, literature documents that even though firms have heterogenous performance, the consequences for the aggregate level are important - aggregate productivity could be lower due to institutional setting in a country. If, for example, the market forces in a country are underdeveloped, this could enable the low performing firms to maintain in operation (Syverson, 2011). As long as country institutional setting encompass barriers to entry or skills mismatch, the firm heterogeneity can determine the aggregate productivity path.

\section{CONCLUSIONS}

This paper explores productivity in post-transition economies at the level of firms. By relying on a unique dataset that enables comparison across different economies, common factors contributing to the estimated TFP are sought. Our analysis identifies higher TFP estimates in service sector firms in comparison to manufacturing firms when tfprYKL is taken into account and contrary when tfprYKLM is analysed. We have thus identified that average country level TFP estimates differ conditional upon the method of estimation. The identification of the distance of individual countries from the production frontier is strongly dependent upon the underlying assumption of the estimation strategy.

Possibly unsurprising result of the empirical exercise in this paper is that firm-level TFP is best explained by the idiosyncratic country-level conditions in post-transition economies. This would suggest that for the productivity enhancements, each country should aim to create its own policy mix that will subsequently lead to the improvement on the national level. The speed of catching up of different firms within national economies seems to be correlated with the general economic conditions in each economy. It is important to notice that such conclusion also encompasses the important constraint of the estimation results - specific firm level productivity components, such as the quality of human capital as a particular product of country educational system, are incorporated in the idiosyncratic country effects.

Firms in post-transition economies generally still have not reached the level of innovativeness and use of advanced ICT of developed economies. Our results reveal that, unlike firms in developed economies, those who engaged in innovation activities and have adopted ICT infrastructures do not benefit from it in terms of productivity growth, at least not in the short run. This points out to important difference between post-transition and more advanced market economies and presents important issue to be explored in more depth. Future studies should consider significance of different types of innovation as well as R\&D intensity for productivity in post-transition economies. Another possible venue for future research is to incorporate evolution of the firms and their adaptation to the changing economic conditions. This would, however, require panel dataset. 


\section{REFERENCES}

Acemoglu, D., \& Zilibotti, F. (2001). Productivity differences. The Quarterly Journal of Economics, 116(2), 563-606.

Angelucci, M., Estrin, S., Konings, J. \& Zolkiewski, Z. (2002). The Effect of Ownership and Competitive Pressure on Firm Performance in Transition Countries: Micro Evidence from Bulgaria, Romania and Poland. William Davidson Working Paper Number 434.

Bah, E.M., \& Brada, J. (2009). Total Factor Productivity Growth, Structural Change and Convergence in the New Members of the European Union. Comparative Economic Studies, 51(4), 421-446.

Bartlesman, E., Haltiwanger, J., \& Scarpetta, S. (2013). Cross-Country Differences in Productivity: The Role of Allocation and Selection. The American Economic Review, 103(1), 305-334.

Benavente, J.M. (2006). The Role of Research and Innovation in Promoting Productivity in Chile. Economics of Innovation and New Technology, 154(5), 301-315.

Byrne, D., \& Corrado, C. (2016). ICT Prices and ICT Services: What do they tell us about Productivity and Technology? Economics Program Working Paper Series, EPWP 16 - 05.

Castellacci, F. (2007). Technological regimes and sectoral differences in productivity growth. Industrial and Corporate Change, 16(6), 1105-1145.

Crépon, B., Duguet, E., \& Mairesse, J. (1998). Research, innovation and productivity: An econometric analysis at the firm level. Economics of Innovation and New Technology, 7(2), 115-158. doi:10.1080/10438599800000031.

Crespi, G., \& Zuniga, P. (2012). Innovation and Productivity: Evidence from Six Latin American Countries. World Development, 40(2), 273-290.

Cusolito, A.P., Francis, D.C., Karalashvili, N., \& Meza, J.R. (2016). Firm Level Productivity Estimates. Development Economics, Enterprise Analysis Unit, the World Bank Group. Retrieved from www.enterprisesurveys.org/.

de la Fuente, A. (2011). Human capital and productivity. Nordic Economic Policy Review, 21, 103-133.

Dowrick, S., \& Nguyen, D-T. (1989). OECD Comparative Economic Growth 1950-85: Catch-Up and Convergence. American Economic Review, 79(5), 1010-1030.

Easterly, W., \& Levine, R. (2001). What have we learned from a decade of empirical research on growth? It's Not Factor Accumulation: Stylized Facts and Growth Models. World Bank Economic Review, 15(2), 177-219.

ECB (2017). The slowdown in euro area productivity in a global context. ECB Bulletin, Issue 3/2017. Retrieved from https://www.ecb.europa.eu/pub/pdf/other/ebart201703_01.en.pdf?4673f85cee30bf05ebeae2b9faac3cf8

European Commission (2017). European Innovation Scoreboard 2017. Retrieved from http:/ / ec.europa.eu/DocsRoom/documents/24829

Goedhuys, M. (2007). The impact of innovation activities on productivity and firm growth: evidence from Brazil. UNU-MERIT Working Paper Series, 02.

Griffith, R., Huergo, E., Mairesse, J., \& Peters, B. (2006). Innovation and Productivity across Four European Countries. Oxford Review of Economic Policy, 22(4), 483-498.

Hall, B.H., \& Mairesse, J. (2006). Empirical studies of innovation in the knowledge-driven economy. Economics of Innovation and New Technology, 154(4/5), 289-299.

Hall, R., \& Jones, C.I. (1999). Why Do Some Countries Produce So Much More Output per Worker Than Others? The Quarterly Journal of Economics, 114(1), 83-116.

Harrigan, J. (1999). Estimation of Cross-Country Differences in Aggregate Production Functions. Journal of International Economics, 47(2), 267-93.

Helpman, E. (2004). The Mystery of Economic Growth. Cambridge: Harvard University Press.

Hulten, C.R. (2001). Total Factor Productivity. A Short Biography. In Hulten, C. R., Dean, E. R. \& Harper, M. J. (Eds.), New Developments in Productivity Analysis (pp. 1-54). Chicago: University of Chicago Press.

İmrohoroğlu, A., \& Tüzel, Ş. (2014). Firm level productivity, risk, and return. Management Science, 60(8), 2073-2090. doi: $10.1287 /$ mnsc.2013.1852.

Issakson, A. (2007). Determinants of total factor productivity: a literature review. UNIDO Staff Working Paper, 02.

Jung, M., \& Lee, K. (2010). Sectoral systems of innovation and productivity catch-up: determinants of the productivity gap between Korean and Japanese firms. Industrial and Corporate Change, 19(4), 1037-1069. doi: $10.1093 /$ icc/dtp054. 
Krugman, P. (1994). The Myth of Asia's Miracle. Foreign Affairs, 73(6), 62-78.

Levinsohn, J., \& Petrin, A. (2003). Estimating Production Functions Using Inputs to Control for Unobservables. Review of Economic Studies, 70(2), 317-341.

Lynch, L.M., \& Black, S. E. (1996). Beyond the Incidence of Training: Evidence from a National Employers Survey. NBER Working Paper, 5231.

Mohnen, P., \& Hall, B.H. (2013). Innovation and productivity: an update. Eurasian Business Review, 3(1), 47-65. doi:10.14208/BF03353817.

OECD. (2015). The Future of Productivity. Retrieved from http://www.oecd-ilibrary.org/economics/the-future-ofproductivity 9789264248533 -en.

Olley, S., \& Pakes, A. (1996). The Dynamics of Productivity in the Telecommunications Equipment Industry, Econometrica, 64(6), 1263-1298.

Pianta, M., \& Vaona, A. (2007). Innovation and Productivity in European Industries. Economics of Innovation and New Technology, 16(7), 485-499. doi:10.1080/10438590600914569.

Raguž, I., Družić, I. \& Tica, J. (2012). Impact of the transition on the TFP in Croatia. FEB - Working Paper Series, $12-$ 05 .

Romer, P.M. (1993). Idea Gaps and Object Gaps in Economic Development. Journal of Monetary Economics, 32(3), 543573. doi:10.1016/0304-3932(93)90029-F.

Solow, R.M. (1957). Technical Change and the Aggregate Production Function. Review of Economics and Statistics, 39(3), 312-320.

Syverson, C. (2011). What Determines Productivity?. Journal of Economic Literature, 49(2), 326-365.

Van Beveren, I. (2010). Total factor productivity estimation: a practical review. Journal of Economic Surveys, 26(1), 98128.

Wang, Y., \& Yao, Y. (2003). Sources of China's economic growth 1952-1999: incorporating human capital accumulation. China Economic Review, 14, 32-52. 


\section{APPENDIX}

Table A1

Estiamted coefficients, standard errors, t-stats and p-values for results presented in Table 2 in the text

\begin{tabular}{|c|c|c|c|c|c|c|c|c|}
\hline & \multicolumn{4}{|c|}{$\begin{array}{c}\text { dependent variable: } \\
\text { tfprYKL }\end{array}$} & \multicolumn{4}{|c|}{$\begin{array}{c}\text { dependent variable: } \\
\text { tfprYKLM }\end{array}$} \\
\hline & coefficient & $\begin{array}{l}\text { Standard } \\
\text { error }\end{array}$ & t-value & p-value & coefficient & $\begin{array}{c}\text { Standard } \\
\text { error }\end{array}$ & t-value & p-value \\
\hline Constant & 3.63 & 0.23 & 15.99 & 0.00 & 2.40 & 0.19 & 12.43 & 0.00 \\
\hline Innovative firm & 0.01 & 0.12 & 0.07 & 0.95 & -0.16 & 0.10 & -1.54 & 0.13 \\
\hline \multicolumn{9}{|l|}{ Size of the firm } \\
\hline Micro & -1.23 & 0.47 & -2.61 & 0.01 & -0.74 & 0.40 & -1.85 & 0.06 \\
\hline Small & -0.12 & 0.13 & -0.94 & 0.35 & -0.14 & 0.12 & -1.21 & 0.23 \\
\hline Large & -0.04 & 0.17 & -0.21 & 0.83 & -0.07 & 0.15 & -0.50 & 0.62 \\
\hline Internet & -0.25 & 0.16 & -1.56 & 0.12 & -0.13 & 0.14 & -0.92 & 0.36 \\
\hline Web & 0.03 & 0.13 & 0.23 & 0.82 & 0.14 & 0.12 & 1.16 & 0.25 \\
\hline Technology_licence & -0.29 & 0.15 & -1.94 & 0.05 & -0.12 & 0.13 & -0.91 & 0.36 \\
\hline Foreign_material & 0.00 & 0.00 & 0.45 & 0.65 & 0.00 & 0.00 & 0.76 & 0.45 \\
\hline Export_share & 0.01 & 0.00 & 1.90 & 0.06 & 0.01 & 0.00 & 2.85 & 0.01 \\
\hline \multicolumn{9}{|l|}{$\begin{array}{l}\text { Establishment } \\
\text { formation }\end{array}$} \\
\hline State & 0.15 & 0.55 & 0.27 & 0.79 & 0.08 & 0.44 & 0.18 & 0.86 \\
\hline Joint & 0.24 & 0.60 & 0.40 & 0.69 & 0.41 & 0.48 & 0.85 & 0.40 \\
\hline Privatization & -0.20 & 0.20 & -1.02 & 0.31 & 0.00 & 0.17 & 0.01 & 0.99 \\
\hline Subsidiary & -0.28 & 0.60 & -0.47 & 0.64 & -0.08 & 0.48 & -0.17 & 0.87 \\
\hline \multicolumn{9}{|l|}{ Countries } \\
\hline Georgia & -1.22 & 0.37 & -3.28 & 0.00 & -0.25 & 0.33 & -0.76 & 0.45 \\
\hline Turkey & -1.23 & 0.17 & -7.18 & 0.00 & 0.32 & 0.15 & 2.16 & 0.03 \\
\hline Ukraine & -2.02 & 0.18 & -11.00 & 0.00 & 0.56 & 0.15 & 3.68 & 0.00 \\
\hline Romania & -1.59 & 0.41 & -3.92 & 0.00 & 0.32 & 0.34 & 0.95 & 0.34 \\
\hline $\begin{array}{l}\text { Bosnia and } \\
\text { Herzegovina }\end{array}$ & -1.16 & 0.36 & -3.19 & 0.00 & -2.18 & 0.32 & -6.88 & 0.00 \\
\hline FYR Macedonia & -1.06 & 0.33 & -3.19 & 0.00 & 0.27 & 0.28 & 0.98 & 0.33 \\
\hline Mongolia & -1.33 & 0.40 & -3.36 & 0.00 & 0.48 & 0.32 & 1.52 & 0.13 \\
\hline Slovenia & -1.95 & 0.41 & -4.75 & 0.00 & -1.31 & 0.33 & -3.93 & 0.00 \\
\hline Croatia & -2.09 & 0.36 & -5.80 & 0.00 & 0.31 & 0.29 & 1.08 & 0.28 \\
\hline
\end{tabular}

Source: authors' estimates based on WB data. 